\title{
Vegetation control and fertilization in midrotation Pinus taeda stands in the southeastern United States
}

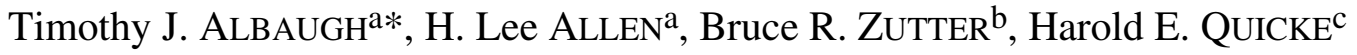 \\ a Department of Forestry, North Carolina State University, Box 8008, Raleigh, NC 27695-8008, USA \\ b Auburn University, Auburn, AL, USA \\ c BASF Corporation, Auburn, AL, USA
}

(Received 5 July 2002; accepted 24 February 203)

\begin{abstract}
We quantified Pinus taeda L. plantation response to vegetation control (VC) applied using site specific methods including chemical (glyphosate, imazapyr, metsulfuron methyl, and triclopyr) and mechanical means and nitrogen and phosphorus fertilization on a variety of sites ranging in age from ten to twenty-two years old at treatment initiation in the Piedmont and coastal plain of the southeastern United States. We examined pine and hardwood (the primary competing vegetation) basal area and pine volume and foliar nutrient responses in a $2 \times 2$ factorial combination of a one time application of $\mathrm{VC}$ and fertilization in a randomized complete block design with three or four replications at each site. Vegetation control reduced hardwood vegetation at least $70 \%$ at all sites. On average, annual pine volume growth response was greatest on the combined treatment $\left(6.1\right.$ and $\left.11.0 \mathrm{~m}^{3} \mathrm{ha}^{-1} \mathrm{yr}^{-1}\right)$ followed by fertilization alone $\left(5.5\right.$ and $\left.7.9 \mathrm{~m}^{3} \mathrm{ha}^{-1} \mathrm{yr}^{-1}\right)$ and then $\mathrm{VC}$ alone $(1.1$ and $4.5 \mathrm{~m}^{3} \mathrm{ha}^{-1} \mathrm{yr}^{-1}$ ) for years one and two and years three and four, respectively. The range in pine volume response across all treatments for the sites examined here was -3 to $12 \mathrm{~m}^{3} \mathrm{ha}^{-1} \mathrm{yr}^{-1}$. There may be sites, not represented here, with greater water deficits, more competing vegetation, or where nitrogen and phosphorus are not the primary limiting factor that would be more responsive to VC. Fertilization alone did not significantly affect hardwood basal area at year two or four and the proportion of hardwood vegetation (as basal area) was about the same before treatment $(12 \%)$ and up to four years after treatment (11\%) in the check and fertilized treatments. We hypothesize that the combined treatment may provide the best pine response in later measurement periods as fertilization responses diminish because added nutrients are utilized and $\mathrm{VC}$ responses increase from increased nutrient and moisture availability to the pines provided the competing vegetation does not recover.
\end{abstract}

vegetation control / fertilization / nitrogen / phosphorus / pine

Résumé - Contrôle de la végétation et fertilisation de peuplements de Pinus taeda à mi-révolution dans les états du Sud-Est des USA. Nous avons évalué l'effet sur des plantations de Pinus taeda L. de différentes méthodes de contrôle de la végétation (VC) à savoir des traitements chimiques (glyphosate, imazapyr, metsulfuron, methyl et triclopyr), des interventions mécaniques et une fertilisation phosphatée, ceci sur un ensemble de stations situées en plaine et en piedmont des Etats du Sud Ouest, portant des peuplements allant de 10 à 22 ans en début d'expérience. Nous avons étudié la surface terrière des pins et des feuillus (principale végétation concurrente) ainsi que le volume et la composition foliaire en nutrients des pins dans un dispositif en bloc complet à 2 ou 3 répétitions, avec une combinaison factorielle $2 \times 2$ d'une seule application de VC et de fertilisation. Le contrôle de la végétation réduit l'importance des feuillus de $70 \%$ au moins, sur toutes les stations.

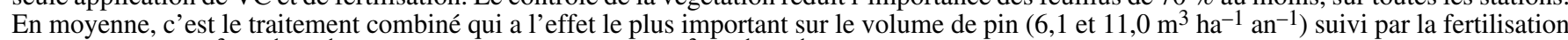
seule $\left(5,5\right.$ et $\left.7,9 \mathrm{~m}^{3} \mathrm{ha}^{-1} \mathrm{an}^{-1}\right)$ et par le VC seul $\left(1,1\right.$ et $\left.4,5 \mathrm{~m}^{3} \mathrm{ha}^{-1} \mathrm{an}^{-1}\right)$, les deux nombres entre parenthèses correspondant aux années 1 et, puis 3 et 4 . L'amplitude de l'effet sur le volume des pins pour l'ensemble des traitements et des stations va de -3 à $12 \mathrm{~m}^{3} \mathrm{ha}^{-1} \mathrm{an}^{-1}$. Il est possible que certains stations, non représentées ici, caractérisées par un plus grand déficit en eau, une concurrence plus importante et des disponibilités suffisantes en azote et phosphore, puissent réagir de manière plus importante aux traitements de contrôle de la végétation. La fertilisation seule n'a pas d'effet significatif sur la surface terrière des feuillus aux années 2 et 4 ; la proportion de feuillus en surface terrière est à peu près la même avant et après traitement (12 et $11 \%$ ) dans les parcelles témoins et fertilisées. Pour expliquer la supériorité du traitement combiné sur la croissance des pins au bout de 4 ans, nous émettons l'hypothèse suivante : l'effet fertilisation tend à diminuer, les nutrients apportés ayant été utilisés, mais l'effet VC augmente compte tenu de l'augmentation des disponibilités en nutrients et en eau au profit des pins, la végétation concurrente ne pouvant pas se développer.

contrôle de la végétation / fertilisation / azote / phosphore / pin

\section{INTRODUCTION}

Nutrient and water limitations may reduce pine stand growth by reducing foliage production and longevity, and photosynthesis rates [1]. Loblolly pine (Pinus taeda L.) is the principal commercial tree species in the southeast United States, and understanding the resources limiting its growth will be important from an economic and scientific point of

* Corresponding author: tim_albaugh@ncsu.edu 
Table I. Pre-treatment site characterizations and treatment applications ${ }^{a}$.

\begin{tabular}{|c|c|c|c|c|c|c|c|c|c|c|c|c|c|}
\hline \multirow{3}{*}{ Study $b c$} & \multirow{3}{*}{ State } & \multirow{3}{*}{$\begin{array}{c}\text { Year } \\
\text { installed }\end{array}$} & \multirow{3}{*}{ Age } & \multicolumn{6}{|c|}{ Pine } & \multirow{2}{*}{\multicolumn{2}{|c|}{$\begin{array}{l}\text { Hardwood } \\
\text { Basal area }\end{array}$}} & \multirow{2}{*}{\multicolumn{2}{|c|}{ Vegetation control }} \\
\hline & & & & \multicolumn{2}{|c|}{ Stem density } & \multicolumn{2}{|c|}{ Height } & \multicolumn{2}{|c|}{ Basal area } & & & & \\
\hline & & & & Stems ha ${ }^{-1}$ & $\mathrm{se}^{d}$ & $\mathrm{~m}$ & se & $\mathrm{m}^{2} \mathrm{ha}^{-1}$ & $\mathrm{se}$ & $\mathrm{m}^{2} \mathrm{ha}^{-1}$ & se & Herbicide & Application \\
\hline 1201 & $\mathrm{AL}$ & 1999 & 12 & 1581 & 49 & 9.5 & 0.2 & 22.0 & 0.8 & 1.3 & 0.1 & $12 \mathrm{~L} \mathrm{ha}^{-1}$ imazapyr & Helicopter \\
\hline 1301 & $\mathrm{NC}$ & 1998 & 14 & 1212 & 74 & 13.1 & 0.2 & 26.1 & 1.1 & 8.9 & 0.6 & $\begin{array}{l}50 \% \text { triclopyr solution, } \\
\text { followup with glyphosate }\end{array}$ & $\begin{array}{c}\text { Spray } \\
\text { stumps and } \\
\text { regrowth }\end{array}$ \\
\hline 2601 & $\mathrm{AL}$ & 1996 & 10 & 1584 & 57 & 8.6 & 0.1 & 15.4 & 0.6 & 2.6 & 0.2 & $\begin{array}{l}12 \mathrm{~L} \mathrm{ha}^{-1} \text { imazapyr }+1 \mathrm{~L} \mathrm{ha} \mathrm{ha}^{-1} \\
\text { metsulfuron methyl }\end{array}$ & Helicopter \\
\hline 2602 & $\mathrm{NC}$ & 1999 & 12 & 640 & 13 & 12.9 & 0.2 & 17.7 & 0.4 & 1.5 & 0.2 & $9 \mathrm{~L} \mathrm{ha}^{-1}$ imazapyr & Skidder \\
\hline 3002 & GA & 1999 & 12 & 1985 & 41 & 9.7 & 0.1 & 24.9 & 0.4 & 2.2 & 0.2 & $12 \mathrm{~L} \mathrm{ha}^{-1}$ imazapyr $+0.25 \%$ & Helicopter \\
\hline 3901 & $\mathrm{AL}$ & 1998 & 18 & 538 & 12 & 15.5 & 0.2 & 18.0 & 0.4 & 1.4 & 0.2 & $12 \mathrm{~L} \mathrm{ha}^{-1}$ imazapyr & Helicopter \\
\hline 4001 & $\mathrm{SC}$ & 1997 & 22 & 498 & 13 & 16.4 & 0.1 & 18.5 & 0.3 & 3.1 & 0.3 & $\begin{array}{l}92 \mathrm{~kg} \mathrm{ha}^{-1} \text { hexazione } e^{e} \text { and } 25 \% \\
\text { solution imazapyr in water }\end{array}$ & $\begin{array}{l}\text { Spotgun and } \\
\text { injection }\end{array}$ \\
\hline 4301 & GA & 1997 & 14 & 1508 & 29 & 12.3 & 0.1 & 29.7 & 0.4 & 2.5 & 0.2 & $12 \mathrm{~L} \mathrm{ha}^{-1}$ imazapyr $+0.25 \%$ & Helicopter \\
\hline
\end{tabular}

${ }^{a}$ All sites had fertilizer application of $224 \mathrm{~kg} \mathrm{ha}^{-1}$ elemental $\mathrm{N}$ and $56 \mathrm{~kg} \mathrm{ha}^{-1}$ elemental $\mathrm{P}$.

${ }^{b}$ Studies installed on NCSFNC member company land holdings.

${ }^{c} 2602,3901$ and 4001 were thinned prior to establishment.

${ }^{d}$ Standard error.

${ }^{e}$ The hexazinone was ineffective so the imazapyr actually controlled the competing vegetation.

view. Control of competing vegetation reallocates nutrient and water resources used by the competing vegetation to the crop species [2] and may alter site conditions to increase soil nutrient supply. Fertilization directly impacts nutrient availability [3] and has a more indirect impact on water use efficiency [9]. Since both, vegetation control (VC) and fertilization, can impact the same resources but in different ways they may be substitutes or they may create a synergistic result when applied together. Quantification of pine and competing vegetation response to $\mathrm{VC}$ and fertilization applied singly or in combination is a necessary step in understanding the primary resource limitation to pine growth.

In the past, there has been much research examining VC and fertilization when applied individually. Pines have consistently exhibited positive growth responses to control of both herbaceous and woody competing vegetation during the first few years following planting $[6-8,15,17,19]$. However, the beneficial effects of a single application of $\mathrm{VC}$ following crown closure, are not as well documented [25]. Significant increases in loblolly and slash (P. elliottii) pine growth following complete and sustained vegetation control have been observed [11, 20]. Positive growth responses to nitrogen and phosphorus applications in mid-rotation loblolly pine plantations have been well documented across a variety of sites and stand conditions in the southeastern United States [2, 10, 16].

More recently studies have reported significant growth gains relative to check for VC and fertilization applied singly and when combined for applications at the time of planting [4, 18, 21-23]. Powers and Reynolds found that in P. ponderosa systems with extended summer droughts and infertile soils the primary limitation to growth was first soil moisture availability and secondarily nutritional limitations [23]. Hanna found changes in soil moisture and $\mathrm{N}$ availability due to treatment in an examination of mid-rotation application of VC and fertilization to a stand with different levels of initial competing hardwood vegetation on one site in the southeast United States $[13,14]$. Soil moisture availability was increased with VC and reduced with fertilization while $\mathrm{N}$ availability was increased with low levels of competing hardwoods or when combined with the application of VC. Regardless of the assessments of soil moisture and $\mathrm{N}$ availability two years after treatment, the fertilized stands produced more volume growth than the VC treated stands, however the combined treatment out performed either treatment applied alone. Hanna's work [13, 14] was completed at one site where differing levels of competing vegetation were identified for treatment purposes and hence may not represent the response to these treatments under a variety of stand and environmental conditions.

Our objective was to quantify loblolly pine volume growth and foliar nutrient concentration response to a one-time treatment of VC and fertilization applied singly and in combination over a wide range of sites in the southeastern United States. In addition, we examined the effects of fertilization alone on the basal area growth of pines and competing hardwoods.

\section{METHODS}

Eight studies were installed from 1996 to 1999 on a range of sites with varying amounts of competing vegetation (Tab. I). The studies were installed in Alabama, Georgia, North and South Carolina by members of the North Carolina State Forest Nutrition and the Auburn University Silvicultural Herbicide Cooperatives. Seven sites (1201, 1301, 2601, 3002, 3901, 4001 and 4301) were well-drained upland 


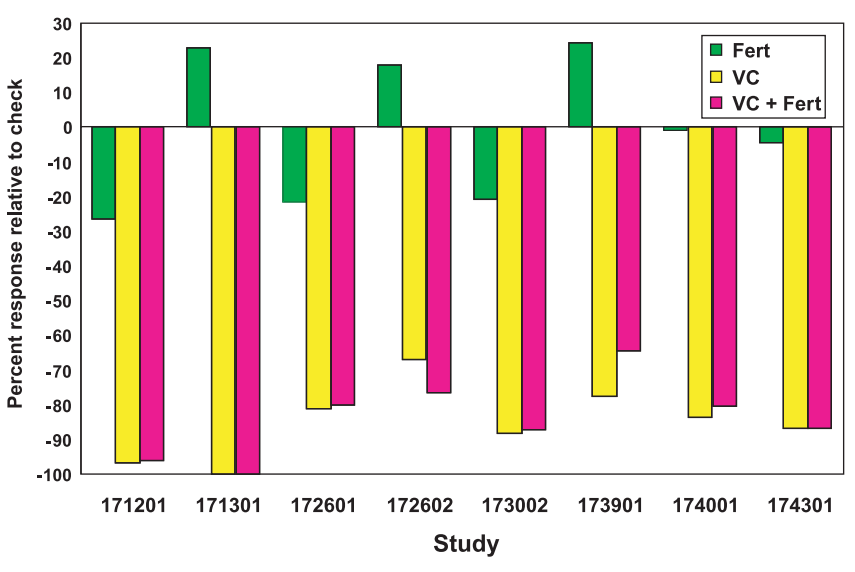

Figure 1. Response relative to check plot hardwood basal area two years after treatments were applied for the eight study sites.

sites and one site (2602) was a poorly drained coastal plain site. All sites have data two growing seasons after treatment and 2601, 3901, 4001 and 4301 have data for four growing seasons after treatment with the following exceptions: no foliar nutrient data were available for 3002 and hardwood measurements were not completed at 3901 four growing seasons after treatment

The experimental design was a $2 \times 2$ factorial of $\mathrm{VC}$ and fertilization replicated three or four times in a randomized complete block design at each site. All installations were selected and blocked to minimize pretreatment variation in dominant height, volume, basal area, and stocking of the planted pines, and hardwood basal area. Plots were at least 0.04 hectares with at least 40 planted pines and surrounded by a treated buffer. Check plots received no treatment. Vegetation control was accomplished by a one-time application of herbicides applied in the fall prior to the installation year (Tab. I). Fertilization was a one-time application of 224 and $56 \mathrm{~kg} \mathrm{ha}^{-1}$ of elemental nitrogen $(\mathrm{N})$ (as urea and diammonium phosphate) and phosphorus ( $\mathrm{P}$ ) (as diammonium phosphate), respectively, and applied in the spring of the year installed. The combined VC and fertilization treatment was the same used for the individual treatments but applied together.

Height and diameter of planted pines and hardwood rootstocks greater than $1.4 \mathrm{~m}$ in height were measured in the dormant season (December to February) prior to establishment and two and four growing seasons after establishment. Individual pine tree volumes were calculated using $\left[\mathrm{V}_{\mathrm{ob}}=0.02364+0.00275 \times \mathrm{D}^{2} \mathrm{H}\right]$ where $\mathrm{V}_{\mathrm{ob}}$ is volume outside bark, $\mathrm{D}$ is diameter at breast height $(1.4 \mathrm{~m})$ and $\mathrm{H}$ is total tree height [27]. Stand volume estimates were the sum of all individual tree volumes scaled to a hectare basis. Foliage was collected from five dominant or co-dominant pine trees in each plot (same five at each collection) during the dormant season after two and four growing seasons. Foliage was collected from the first flush foliage on a primary lateral branch in the upper one-third of the live crown. Foliage samples were dried to a constant weight at $65^{\circ} \mathrm{C}$, ground and analyzed for nutrients using $\mathrm{CHN}$ (for nitrogen) and a nitric acid digest and ICP analysis for all other elements.

Analysis of variance (ANOVA) was used to test for the VC, fertilization, and $\mathrm{VC}$ by fertilization interaction effects on the measured pine and hardwood growth parameters using SAS [26]. Block, VC and fertilization were assigned as class variables in the ANOVA so the typical model statement was DV $=\mathrm{B}$ VC F VC*F where DV was the dependent variable, $\mathrm{B}$ was block, $\mathrm{VC}$ was vegetation control and F was fertilization. All significance levels were $p<0.05$.

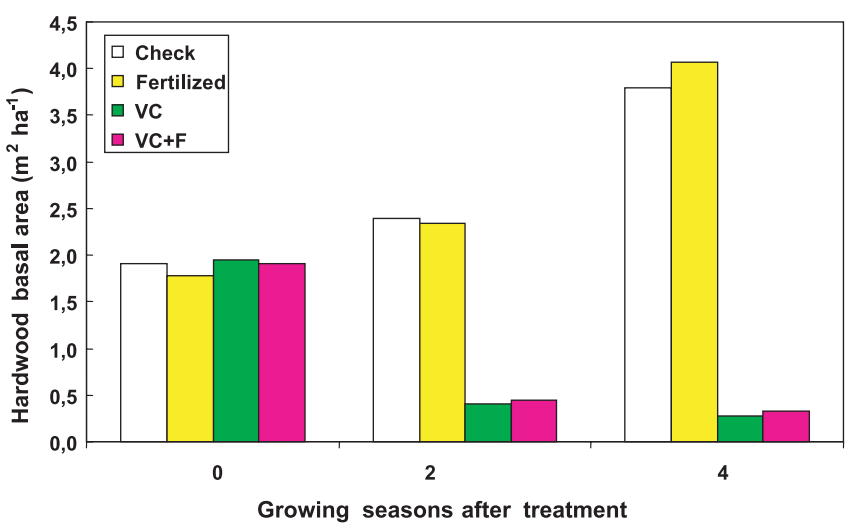

Figure 2. Hardwood basal area prior to treatment (growing seasons after treatment $=0$ ), two and four growing seasons after treatment. Year 0 and 2 are means from five sites $(1201,2602,3002,3901$, $4001)$ and year 4 is from one site (4001).

\section{RESULTS}

Hardwood basal area was significantly reduced by at least $70 \%$ at all sites with the applied vegetation control treatment (Fig. 1). However, the applied VC treatment at three of the eight sites (1301, 2601 and 4301) also adversely affected the pine trees. At 1301, competing pines ( $P$. virginiana) were cut at the base and these stumps were inadvertently treated with triclopyr which damaged the crop pines through root grafts. At 2601, the chemicals applied (imazapyr and metsulfuron methyl) have the same mode of action and resulted in a dose great enough to damage the crop pines. Finally, at 4301, a surfactant labeled for site preparation, not release, was used which resulted in damage to the crop pines. Consequently, these three sites were not included in the analyses involving the VC treatment; however, these sites were used for analyses involving only the examination of check and fertilization treatment growth responses.

On the VC treatments, average hardwood basal area remaining two (from 1201, 2602, 3002, 3901 and 4001) and four (from 4001) years after treatment was 0.42 (maximum of 0.73 and minimum of $0.06 \mathrm{~m}^{2} \mathrm{ha}^{-1}$ ) and $0.30 \mathrm{~m}^{2} \mathrm{ha}^{-1}$, respectively (Fig. 2). Corresponding average hardwood basal area on the check treatment was 2.4 (maximum of 2.1 and minimum of $3.0 \mathrm{~m}^{2} \mathrm{ha}^{-1}$ ) and $3.8 \mathrm{~m}^{2} \mathrm{ha}^{-1}$ and on the fertilized treatment 2.3 (maximum of 1.6 and minimum of $2.9 \mathrm{~m}^{2} \mathrm{ha}^{-1}$ ) and $4.1 \mathrm{~m}^{2} \mathrm{ha}^{-1}$ two and four years after treatment, respectively (Fig. 2).

Foliar $\mathrm{N}$ and $\mathrm{P}$ concentrations were, on average, elevated with VC but the response was not significant at any of the sites measured (1201, 2602, 3901 and 4001). Foliar N and P concentrations were significantly increased on the fertilized treatments at these sites two years after treatment. Check treatment foliar $\mathrm{N}$ and $\mathrm{P}$ average concentrations and standard deviations (in parentheses) were $1.21 \%(0.12)$ and $0.114 \%(0.014)$, respectively. The average response in the fertilized treatment relative to the check $\mathrm{N}$ and $\mathrm{P}$ concentrations was 17 and $18 \%$, respectively (Fig. 3). The combined treatment resulted in an average increase in $\mathrm{N}$ and $\mathrm{P}$ concentration relative to the check of 24 and $22 \%$, respectively (Fig. 3 ).

Of the five sites $(1201,2602,3002,3901$ and 4001), VC treatments resulted in significantly increased volume growth 
Table II. Stand pine volume growth $\left(\mathrm{m}^{3} \mathrm{ha}^{-1}\right)$ and statistics for all sites for each measurement period.

\begin{tabular}{|c|c|c|c|c|c|c|c|c|c|c|}
\hline \multirow{3}{*}{ Studyb } & \multirow{3}{*}{$\begin{array}{l}\text { Check } \\
\text { growth } \\
\mathrm{m}^{3} \mathrm{ha}^{-1}\end{array}$} & \multicolumn{6}{|c|}{ Treatment response $\mathrm{e}^{\mathrm{a}}$} & \multicolumn{3}{|c|}{ Statistics } \\
\hline & & \multicolumn{2}{|c|}{$\mathrm{VC}$} & \multicolumn{2}{|c|}{ Fert } & \multicolumn{2}{|c|}{$\mathrm{VC}+$ Fert } & \multirow[t]{2}{*}{$\mathrm{VC}$} & \multirow{2}{*}{$\begin{array}{c}\text { Fert } \\
p \text { value }\end{array}$} & \multirow[t]{2}{*}{ Fert*VC } \\
\hline & & $\mathrm{m}^{3} \mathrm{ha}^{-1}$ & $\%$ & $\mathrm{~m}^{3} \mathrm{ha}^{-1}$ & $\%$ & $\mathrm{~m}^{3} \mathrm{ha}^{-1}$ & $\%$ & & & \\
\hline \multicolumn{11}{|c|}{ Years 1-2 } \\
\hline 1201 & 53 & -6 & -11 & 13 & 25 & 16 & 31 & 0.765 & 0.004 & 0.350 \\
\hline 1301 & 33 & -6 & -18 & 12 & 37 & -2 & -7 & 0.076 & 0.144 & 0.415 \\
\hline 2601 & 54 & -7 & -12 & 5 & 9 & 7 & 13 & 0.682 & 0.134 & 0.444 \\
\hline 2602 & 38 & 11 & 30 & 9 & 25 & 18 & 49 & 0.022 & 0.053 & 0.761 \\
\hline 3002 & 33 & 3 & 9 & 14 & 38 & 2 & 6 & 0.146 & 0.036 & 0.020 \\
\hline 3901 & 40 & -4 & -5 & 9 & 28 & 11 & 33 & 0.839 & 0.028 & 0.572 \\
\hline 4001 & 36 & 6 & 18 & 11 & 31 & 15 & 41 & 0.028 & 0.001 & 0.477 \\
\hline 4301 & 55 & -10 & -18 & 8 & 15 & 3 & 6 & 0.039 & 0.007 & 0.421 \\
\hline \multicolumn{11}{|c|}{ Years 3-4 } \\
\hline 2601 & 46 & -7 & -16 & 6 & 12 & 18 & 39 & 0.669 & 0.036 & 0.133 \\
\hline 3901 & 28 & 3 & 11 & 13 & 48 & 19 & 70 & 0.458 & 0.031 & 0.797 \\
\hline 4001 & 24 & 16 & 66 & 18 & 77 & 24 & 103 & 0.002 & 0.000 & 0.082 \\
\hline 4301 & 51 & -10 & -20 & -2 & -7 & 5 & 9 & 0.653 & 0.085 & 0.029 \\
\hline \multicolumn{11}{|c|}{ Years 1-4 } \\
\hline 2601 & 100 & -14 & -14 & 10 & 10 & 25 & 25 & 0.973 & 0.054 & 0.214 \\
\hline 3901 & 68 & -1 & -1 & 23 & 33 & 30 & 45 & 0.722 & 0.022 & 0.677 \\
\hline 4001 & 59 & 22 & 37 & 29 & 50 & 39 & 66 & 0.002 & 0.000 & 0.122 \\
\hline 4301 & 106 & -20 & -19 & 6 & 5 & 8 & 8 & 0.155 & 0.017 & 0.086 \\
\hline
\end{tabular}

a Treatments are $\mathrm{VC}=$ vegetation control, Fert $=$ fertilization, $\mathrm{VC}+$ Fert $=$ vegetation control and fertilization .

b Studies 1301, 2601, and 4301 had improperly applied vegetation control treatments, see text.

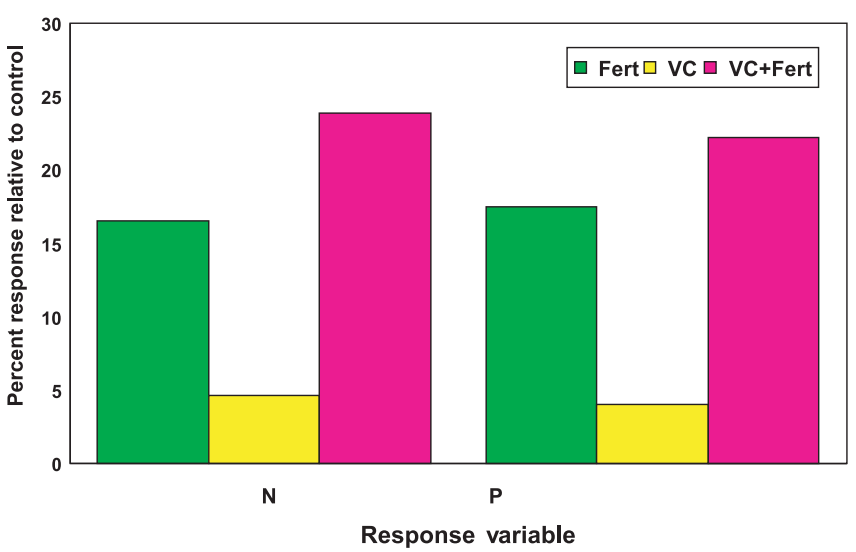

Figure 3. Average $\mathrm{N}$ and $\mathrm{P}$ response relative to check treatment two years after treatment (data from 1201, 2602, 3901, 4001). Average check treatment concentrations were $1.2 \%$ for $\mathrm{N}$ and 0.11 for $\mathrm{P}$.

at two sites with two year data and one site with four year data (Tab. II). The average annual pine volume growth response to VC was 1.1 and $4.5 \mathrm{~m}^{3} \mathrm{ha}^{-1} \mathrm{yr}^{-1}$ for years one and two and years three and four, respectively (Fig. 4). Fertilization resulted in a significant positive pine volume growth response for all five sites with two year data and both sites with four year data (Tab. II). Average annual volume response to fertilization was 5.5 and $7.9 \mathrm{~m}^{3} \mathrm{ha}^{-1} \mathrm{yr}^{-1}$ in years one and two and years three and four, respectively (Tab. II and Fig. 4). The

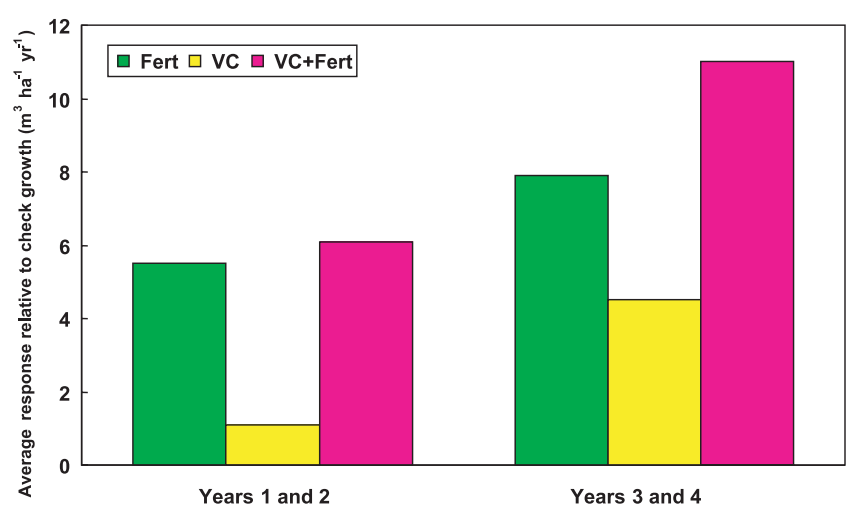

Figure 4. Average annual volume response relative to the check treatment two and four years after treatment.

response to the interaction of $\mathrm{VC}$ and fertilization was not significant. However, the combined treatment (VC and fertilization applied together) was greater than the response to either single treatment at four of the five sites in year two and both sites in year four. The combined treatment response was greater than the sum of the single treatment responses for two sites at year two and for one site at year four. Average annual volume response to the combined treatment was 6.1 and $11.0 \mathrm{~m}^{3} \mathrm{ha}^{-1} \mathrm{yr}^{-1}$ in years one and two and years three and 


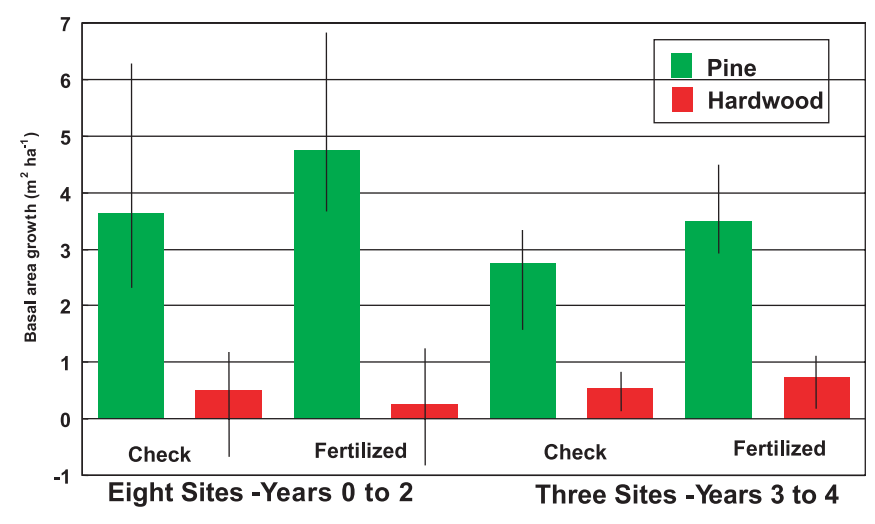

Figure 5. Pine and hardwood basal area growth on the check and fertilized treatments. Bars show average values with minimum and maximum values displayed by the endpoint of the line covering each bar. The two year data are from all eight sites while four year data are from three sites $(2601,4001,4301)$.

four, respectively (Tab. II and Fig. 4). The range in pine volume response over all treatments and years for the sites included here was -3 to $12 \mathrm{~m}^{3} \mathrm{ha}^{-1} \mathrm{yr}^{-1}$ (Tab. II).

Fertilization alone did not significantly affect hardwood basal area at year two or four. In the check and fertilized only plots the average total basal area prior to treatment initiation for all sites and for the sites with four year data (2601, 4001, 4301) was similar at $24 \mathrm{~m}^{2} \mathrm{ha}^{-1}$. Also the proportion of total basal area as hardwood (12\%) was similar for these site and treatment combinations at the beginning of the study. The year two average pine basal area growth (eight sites) in the check and fertilized treatments was 3.6 and $4.8 \mathrm{~m}^{2} \mathrm{ha}^{-1}$, respectively, a $31 \%$ increase with fertilization (Fig. 5). The corresponding average hardwood basal area growth in the check and fertilizer treatments was 0.5 and $0.3 \mathrm{~m}^{2} \mathrm{ha}^{-1}$, respectively, a $47 \%$ decrease with fertilization (Fig. 5). After two years the average (eight sites) total basal area in the check and fertilized plots was 27.9 and $28.9 \mathrm{~m}^{2} \mathrm{ha}^{-1}$, respectively, and the proportion as hardwood was 11 and $10 \%$, respectively. For the three sites with four year data, average pine basal area growth for the third and fourth years after treatment in the check and fertilized treatments was 2.7 and $3.5 \mathrm{~m}^{2} \mathrm{ha}^{-1}$, respectively, a $27 \%$ increase with fertilization (Fig. 5). Average hardwood basal area growth in years three and four in the check and fertilizer treatments was 0.6 and $0.7 \mathrm{~m}^{2} \mathrm{ha}^{-1}$, respectively, a $33 \%$ increase with fertilization (Fig. 5). Consequently, after four years the average total basal area in the check and fertilized plots was 31.9 and $33.4 \mathrm{~m}^{2} \mathrm{ha}^{-1}$, respectively, and the proportion as hardwood was 12 and $11 \%$, respectively. The maximum and minimum pine and hardwood basal area growth for each treatment (check and fertilized alone) and year (two and four years after treatment) combination are shown in Figure 5.

\section{DISCUSSION}

The information for making appropriate vegetation control prescriptions and applications does exist and is available. Unfortunately, this information was not utilized at three sites. Average response when applying VC treatments improperly (sites 1301, 2601, and 4301) was -3.8 and $-4.4 \mathrm{~m}^{3} \mathrm{ha}^{-1} \mathrm{yr}^{-1}$ in years one and two and years three and four, respectively. Assuming the sites could have achieved the average response observed at the five (years 1 and 2) and two (years 3 and 4) sites where VC was properly applied, the cumulative realized loss of volume was $27.6 \mathrm{~m}^{3} \mathrm{ha}^{-1}$ after four years. These data indicate the importance of using the available information for research or operational applications.

Levels of hardwood control were consistent with previous work in young and mid-rotation stands [5, 28]. Hardwoods showed little recovery through year four with the VC treatment. Reported loblolly pine growth responses of $2 \mathrm{~m}^{3} \mathrm{ha}^{-1} \mathrm{yr}^{-1}$ with complete and sustained $\mathrm{VC}$ four years after treatment were similar to those found in this study $[11,20]$.

Over the longer term ( $>4$ years) VC has proven beneficial to pine growth. Seven years after treatment in the Quicke et al. study, the treated pines were 11-22\% taller than check trees even though initial pine stunting was observed [24]. Also, Fortson et al. indicated that the differences in volume in check and $\mathrm{VC}$ treatments continued to diverge up to at least eight years after treatment [12].

Vegetation control may have addressed different resource limitations at the sites where significantly positive growth responses to VC were observed. At 2602, a poorly drained site with a low likelihood of soil moisture limitations (relative to the other study sites), we observed only small increases in foliar N and P levels with VC. However, boron (B) concentrations were increased $17 \%$ relative to the check two years after treatment with $\mathrm{VC}$ and this increase resulted in concentrations above that considered to be a critical level for good growth (12 ppm). This increase in B at 2602 may be a result of the reduction in competing vegetation that allowed the pines to acquire $B$ that the then dead competing vegetation had used when it was alive. Boron is moved along with the transpiration stream and the readily available water at this site would insure that the pines would be able to capture any unused B. At 4001, another site with a significant positive pine volume response to $\mathrm{VC}$, the foliar $\mathrm{N}, \mathrm{P}$, and $\mathrm{B}$ responses were relatively small. Although we did not measure moisture availability, this site is likely to experience droughty conditions during the growing season and we hypothesize that the positive volume responses were a result of improved soil moisture availability. Similar to other studies, our findings indicate that, the primary benefit from VC may be nutritional or moisture related depending on individual site conditions [21, 23]. In future studies, it would be interesting to examine $\mathrm{VC}$ and fertilization responses where fertilization included, in addition to $\mathrm{N}$ and $\mathrm{P}$, a broader selection of nutrients that may be limiting (e.g. boron and potassium).

Clearly $\mathrm{N}$ and $\mathrm{P}$ were important limiting factors at all five sites we examined. Given that all studies exhibited a significant positive response to additions of $\mathrm{N}$ and $\mathrm{P}$, it may be reasonable to conclude that $\mathrm{N}$ and $\mathrm{P}$ availability were the primary limiting factor for pine growth. However, once $\mathrm{N}$ and $\mathrm{P}$ limitations were ameliorated, other factors limiting growth may have been ameliorated by $\mathrm{VC}$ since the combined treatment responded, on average, more than either treatment applied alone.

This is the first study to quantify the response of competing vegetation to fertilization in mid-rotation on a number of sites with similar treatments. The proportion of hardwood vegetation (as basal area) at these sites appears to be largely 
unchanged by the fertilizer treatment in that hardwood as a percentage of the total basal area in the stand is about the same before treatment $(12 \%)$ and up to four years after treatment $(11 \%)$. Given the range of competing hardwood amounts, the relatively high applied rates of $\mathrm{N}$ and $\mathrm{P}$, and the broadcast fertilizer application method the net ability to acquire and utilize the added nutrients may be the same for all plants, whether hardwood or pine, in the short term. This is good news for forest managers concerned about fertilizing when competing vegetation is present in a stand at levels similar to those in this study.

From the aspect of resource limitations in these mid-rotation pine stands, the direct application of limited nutrients (fertilization) generally provided a larger positive volume response than the removal of competitors (VC) through four years after treatment when the treatments were applied singly. There may be site types, not represented in this study, with greater seasonal water deficits or more competing vegetation, or where $\mathrm{N}$ and $\mathrm{P}$ are not the primary limiting factor that may prove more responsive to vegetation control in the years following treatment. However, adding limited nutrients and removing competitors (the combined treatment) provided an even better volume response than either single treatment in most cases. In later measurement periods, we would expect the fertilization response to decrease as the added nutrients are utilized by the stand and the $\mathrm{VC}$ response to increase due to increased nutrient and moisture availability to the crop trees provided the competing vegetation does not recover. It remains to be determined how the combined treatment will compare to the single treatments in later measurement periods, however based on current information one could reasonably hypothesize that the combined treatment may prove to be the best one at that time.

Acknowledgments: We appreciate the support provided by the members of the North Carolina State University Forest Nutrition Cooperative and the Auburn Silvicultural Herbicide Cooperative, and the Department of Forestry at North Carolina State University. The use of trade names in this paper does not imply endorsement by the associated agencies of the products named, nor criticism of similar ones not mentioned.

\section{REFERENCES}

[1] Albaugh T.J., Allen H.L., Dougherty P.M., Kress L.W., King J.S., Leaf area and above- and belowground growth responses of loblolly pine to nutrient and water additions, For. Sci. 44 (1998) 317-328.

[2] Allen H.L., Albaugh T.J., Understanding the interactions between vegetation control and fertilization in young plantations: southern pine plantations in the Southeast USA, Instituto de Pesquisas e Estudos Florestais "Il Seminário sobre Manejo de Plantas Infestantes em Áreas Florestais", Department of Forest Soils at ESALQ / Univ. of San Paulo, Brazil, 2000, 14 p.

[3] Allen H.L., Dougherty P.M., Campbell R.G., Manipulation of water and nutrients - practice and opportunity in southern U.S. pine forests, For. Ecol. Manage. 30 (1990) 437-453.

[4] Borders B.E., Bailey R.L., Loblolly pine - pushing the limits of growth, South. J. Appl. For. 25 (2001) 69-74.

[5] Cain M.D., Evaluation of imazapyr for control of woody competitors in a plantation of submerchantable-size loblolly pine, USDA For. Serv. South. For. Exp. Sta. Res. Pap. SO-262, 1991, 11 p.

[6] Cain M.D., Mann W.F. Jr., Annual brush control increases early growth of loblolly pine, South. J. Appl. For. 4 (1980) 67-70.

[7] Colbert S.R., Jokela E.J., Neary D.G., Effects of annual fertilization and sustained weed control on dry matter partitioning, leaf area, and growth efficiency of juvenile loblolly and slash pine, For. Sci. 36 (1990) 995-1014.

[8] Creighton J.L., Zutter B.R. Glover G.R., Gjerstad D.H., Planted pine growth and survival response to herbaceous vegetation control, treatment duration, and herbicide application techniques, South. J. Appl. For. 11 (1987) 223-227.

[9] Ewers B.E., Oren R., Albaugh T.J., Dougherty P.M., Carry-over effects of water and nutrient supply on water use of Pinus taeda, Ecol. Appl. 9 (1999) 513-525.

[10] Fisher R.F., Garbett W.S., Response of semimature slash and loblolly pine plantations to fertilization with nitrogen and phosphorus, Soil Sci. Soc. Am. J. 44 (1980) 850-854.

[11] Fortson J.C., Shiver B.D., Shackelford L.S., Ten-year results of the SAGS loblolly pine competing vegetation study. Preliminary Report. Plantation Management Research Cooperative, Univ. of Georgia, Athens, 1994, GA, USA.

[12] Fortson J.C., Shiver B.D., Shackelford L., Removal of competing vegetation from established loblolly pine plantations increases growth on Piedmont and Upper Coastal Plain sites, South. J. Appl. For. 20 (1996) 188-192.

[13] Hanna S.A., Midrotation response of loblolly pine to fertilization and vegetation control, Auburn University, Ph.D. dissertation, 2000, 209 p.

[14] Hanna S.A., Glover G.R., Lockaby B.G., Zutter B.R., Torbert J., Nitrogen response to vegetation control and fertilization in a midrotation loblolly pine stand, Proc. South. Weed Sci. Soc. 52 (1991) 112-113.

[15] Haywood J.D., Response of planted Pinus taeda L. to brush control in northern Louisiana, For. Ecol. Manage. 15 (1986) 129-134.

[16] Hynynen J., Burkhart H.E., Allen H.L., Modeling tree growth in fertilized midrotation loblolly pine plantations, For. Ecol. Manage. 107 (1998) 213-229.

[17] Knowe S.A., Nelson L.R., Gjerstad D.H., Zutter B.R., Glover G.R. Minogue P.J., Dukes J.H., Four-year growth and development of planted loblolly pine on sites with competition control, South. J. Appl. For. 9 (1985) 11-15.

[18] Mason E.G., Milne P.G., Effects of weed control, fertilization, and soil cultivation on the growth of Pinus radiata at midrotation in Canterbury, New Zealand, Can. J. For. Res. 29 (1999) 985-992.

[19] Miller J.H., Zutter B.R., Zedaker S.M., Edwards M.B., Haywood J.D., Newbold R.A., A regional study on the influence of woody and herbaceous competition on early loblolly pine growth, South. J. Appl. For. 15 (1991) 329-334.

[20] Oppenheimer M.J., Shiver B.D., Rheney J.W., Ten-year response of midrotation slash pine plantations to control of competing vegetation, Can. J. For. Res. 19 (1989) 329-334.

[21] Nilsson U., Örlander G., Response of newly planted Norway spruce seedlings to fertilization, irrigation and herbicide treatments, Ann. For. Sci. 60 (2003) 637-643.

[22] Nordborg F., Nilsson U., Growth, damage and net nitrogen uptake in Picea abies (L.) Karst. seedlings, effects of site preparation and fertilization, Ann. For. Sci. 60 (2003) 657-666.

[23] Powers R.F., Reynolds P.E., Ten-year responses of ponderosa pine plantations to repeated vegetation and nutrient control along an environmental gradient, Can. J. For. Res. 29 (1999) 1027-1038.

[24] Quicke H.E., Lauer D.K., Glover G.R., Growth responses following herbicide release of loblolly pine from competing hardwoods in the Virginia Piedmont, South. J. Appl. For. 20 (1996) 177-181.

[25] Russell T.E., Control of understory hardwoods fails to speed growth of pole-size loblolly, USDA For. Serv. Exp. Stn. Note No. 131 (1961) pp. 3-4.

[26] SAS Institute Inc. SAS/STAT User's guide, Release 6.03 edition, Cary, NC, SAS Institute Inc., 1988, 1028 p.

[27] Smalley G.W., Bower D.R., Volume tables and point sampling factors for loblolly pine plantations on abundant fields in Tennessee, Alabama, and Geaorgia Highlands, USDA For. Serv. South. For. Exp. Sta., Res. Pap. SO-32, 1968.

[28] Zutter B.R., Britt J.R., Minogue P.J., Quicke H.E., Response of hardwoods and loblolly pines two years after a midrotation aerial application of Arsenal Applicators Concentrate, American Cyanamid Forestry Tech. Service Research Report 97-02, 1997, 9 p. 